\section{NESTING OF DUSKY CRAG MARTIN PTYONOPROGNE CONCOLOR SYKES ON ELECTRIC BULBS AT PHULWARI AND KUMBHALGARH WILDLIFE SANCTUARIES, RAJASTHAN}

\author{
Satish Kumar Sharma \\ Range Forest Officer, Phulwari Wildlife Sanctuary, Kota, Udaipur, \\ Rajasthan 307025, India.
}

On 3 July 2001 while verifying the store of Mamer Range, one of three ranges of Phulwari Wildlife Sanctuary, I saw a pair of Dusky Crag Martin (Ptyonoprogne concolor Sykes), nesting on a fused electric bulb, present on a vertical wall of the verandah of the Forest Rest House, Mamer. The nest was attached to the upper surface of the bulb and its holder. The bulb was present just above a door.

Similarly on 18 June 2002, at the Range Office Bokhada, one of three ranges of Kumbhalgarh Wildlife Sanctuary, I again noticed a pair of Dusky Crag Martins nesting on a fused electric bulb, present on a vertical wall in the verandah of the office (Fig. 1). The cup-shaped nest of mud was attached in the same manner as seen at Mamer, nearly $100 \mathrm{~km}$ away, south of Bokhada. The bulb was present very close to the ceiling.

Although suitable corners and wall junctions were present in both the localities, the birds opted electric bulbs to build their nests. According to Ali and Ripley (1983), the Dusky Crag Martin built its nest under eaves, archways and road culverts or against rafters in deserted or occupied dwellings, old mosques and tombs and on ceiling of rockcut caves as well as on natural cliffs, usually sheltered by an overhang. According to Roberts (1992), Dusky Crag Martin built its nest on the vertical faces of natural cliffs and quite often on old deserted building, provided it is in the vicinity of steep cliff. These descriptions indicate that nesting on electric bulbs is quite new and interesting hence worth recording.

\section{Acknowledgements}

I thank Shri. Surendra Singh Dhakar, RFO, Mamer and Shri. Laxaman Singh, RFO, Bokhada for the facilities.

\section{References}

Ali, S. and S.D. Ripley (1983). Handbook of the Birds of India and Pakistan. Oxford University Press.

Roberts, T.J. (1992). The Birds of Pakistan. Vol. I. Oxford University Press.

\section{CRYOTHERAPY FOR THE TREATMENT OF DERMATITIS OF TAIL IN CIVET CATS}

\author{
I. Nath ${ }^{1}$, V.S.C Bose ${ }^{2}$, S.K. Panda ${ }^{3}$, B. Mishra ${ }^{4}$ and S.K. \\ Samantray $^{5}$
}

${ }^{1}$ Assistant Professor, ${ }^{2}$ Head, Department of Surgery, ${ }^{3}$ Assistant Professor, Department of Pathology,

Orissa Veterinary College, O.U.A.T., BBSR, Orissa, India.

${ }^{4}$ Senior Veterinary Officer, ${ }^{5}$ Veterinary Officer, Nandankanan Zoo, Orissa, India.

Cryosurgery is used to treat a variety of cancerous and noncancerous diseases in dogs, horses and cats (Krahwinkel Jr. et al., 1976). This paper describes successful treatment of gangrenous dermatitis of tail in five civet cats.

Five civet cats aged about 3-4 years and weighing about $2-5 \mathrm{~kg}$ at Nandankanan Zoo developed ulcerated wounds on their tails. The wounds were treated with betadiene spray for 10 days with no improvement. It was decided to treat the lesion by cryotheraphy using liquid nitrogen. Animals were restrained physically by holding the base of the tail and lifting above the ground while neck was controlled by a ' $\mathrm{Y}$ ' shaped stick to prevent them from biting. Cryosurgery application was done by swab method (Fig. 1) as described by Nath et al. (2002) in a tiger. No topical antibiotic was applied at the site. The wounds healed completely in 15 days.

In these cases, the wounds after betadine spray might have not healed due to chronic infection and self-mutilation. Hence cryotheraphy was undertaken by physical restraint because of the local analgesic effect of cryogen both during the procedure and post-therapeutic period. The wound healed in two weeks without any dressing as the cryogen itself is bactericidal and needs no antibiotic application. This is in agreement with the observations of Lane (1974).

\section{Acknowledgement}

Authors are thankful to the Director, Nandankanan for the facilities provided for the study.

\section{References}

Krahwinkel, Jr. D.J., D.F. Merkley and D.R. Howard (1976). Cryosurgical treatment of cancerous and non-cancerous disease of Dogs. Horses and cats. Journal of Veterinary Medicine Association 169(2): 201-207.

Lane, J.G. (1974). Practical cryosurgery. An introduction for small animal clinician. Journal of Small Animal Practice 15(9): 715-725.

Nath, I., V.S.C. Bose, S.K. Panda, A.T. Rao and S.K. Ray (2002). Perianal fistula in a white tiger cub. Zoos' Print Journal 17(1): 690.

Received 20 November 2002 